\title{
Fatty Acid Requirements of Mycoplasma laidlawii
}

\author{
By S. RAZIN AND S. ROTTEM \\ Department of Clinical Microbiology, Hebrew University- \\ Hadassah Medical School, Jerusalem, Israel
}

(Received 5 July 1963)

\begin{abstract}
SUMMARY
Several strains of Mycoplasma laidlawii were grown in a partially defined medium which contained bovine plasma albumin as the only undefined constituent. Lipid extraction of the albumin abolished its growth-promoting activity. Growth was restored by adding the extracted lipid fraction or by long-chain fatty acids. Of the fatty acids tested oleic acid was the most active in growth promotion; linoleic and linolenic acids were less active; palmitic and stearic acids were inactive. The requirement for oleic acid was satisfied by Tween 80. M. laidlawii was found to split Tween 80 enzymically, liberating free oleic acid. Replacement of bovine albumin by certain degradation products and by oleic acid, methyl oleate or Tween 80 was unsuccessful, nor could bovine albumin be replaced by several polymers known to bind fatty acids or to increase the viscosity of the growth medium.
\end{abstract}

\section{INTRODUCTION}

The study of the nutritional requirements of Mycoplasma laidlawii formed the subject of several previous publications (Razin \& Knight, 1960a, b; Razin, 1962; Razin \& Cohen, 1963). By definition of the inorganic ion, carbohydrate, amino acid, nucleic acid precursor and vitamin requirements of this Mycoplasma, a growth medium was developed whose only undefined component was bovine plasma albumin fraction $V$ (Razin \& Cohen, 1963). The aim of the present study was to elucidate the role of bovine plasma albumin in the growth of M. laidlarii.

\section{METHODS}

Organisms. Mycoplasma laidlawii strain A (PG8) and M. laidlawii strain B (PG9) were kindly provided by Dr D. G. ff. Edward (Wellcome Research Laboratories, Beckenham, Kent). A strain culturally and biochemically resembling $M$. laidlawii was isolated in our laboratory from the oral cavity of a healthy subject (Razin, Michmann \& Shimshoni, 1964); this will be referred to as the 'oral strain'. M. laidlawii strain A was used for most of the work described.

Media. A modified Edward medium (Razin \& Oliver, 1961) was used for keeping stock cultures and for growing the organisms which served as inoculum in the nutrition experiments. The nutrition experiments were done in the partially defined medium described by Razin \& Cohen (1963) and called 'minimal' medium. This medium contained inorganic salts, amino acids, vitamins, nucleosides, glucose and bovine plasma albumin fraction $\mathrm{V}$. The medium was dispensed in $5 \mathrm{ml}$. quantities into acid-washed sterile screw-capped test-tubes.

Conditions of growth. The organisms were grown in $5 \mathrm{ml}$. liquid Edward medium 
for $24 \mathrm{hr}$. at $37^{\circ}$, harvested and washed once with a cold $0.4 \mathrm{M}$-sucrose solution, containing 0.01 $\mathrm{M}$-phosphate buffer $(\mathrm{pH} \mathrm{7 \cdot 0)}$ and resuspended in the same solution (Rodwell \& Abbot, 1961). Each tube of experimental medium received $0 \cdot 2 \mathrm{ml}$. of a $1 / 5$ dilution of washed organism suspension. The initial inoculum contained about $10^{6}$ viable particles $/ \mathrm{ml}$. medium, as determined by the colony count technique of Butler \& Knight $(1960 a)$. Inoculated tubes were incubated statically in air at $37^{\circ}$. Growth was usually estimated after incubation for $96 \mathrm{hr}$.

Assessment of growth. The extent of growth was measured by titration of the acid formed by the organisms during growth (Razin \& Knight, 1960a) or by the viable count technique as described by Butler \& Knight (1960a).

Chemicals. Tween 80 (City Chemical Co., New York) was purified by ether extraction according to Davis (1947). Tween 20, Tween 40 and Tween 60 were the products of Atlas Powder Co. (Wilmington, Delaware, U.S.A.), and were used without further purification. Sterilization of the Tween solutions was done by autoclaving for $10 \mathrm{~min}$. at $121^{\circ}$. Oleic acid (99\% pure), linoleic acid (99.5\% pure), linolenic acid (highly purified), lauric acid (highly purified), palmitic acid (99\% pure) stearic acid (99\% pure), methyl oleate (99\% pure), were all products of Nutritional Biochemicals Corporation (Cleveland, Ohio, U.S.A.). Concentrated solutions of fatty acids were prepared in ethanol and diluted as required in sterile 'minimal' medium. The resulting emulsions were added in $0.5 \mathrm{ml}$. quantities to $4.5 \mathrm{ml}$. of the test media. Cholesterol (Nutritional Biochemicals Corporation) was dissolved in warm ethanol and the solution sterilized by filtration. Cholesterol was added to the growth medium by injection of small volumes of warm ethanolic solution by syringe. Methylcellulose (viscosity $2000 \mathrm{cp}$; Dow Chemical Co., Midland, Michigan, U.S.A.) was dissolved in de-ionized water by heating at $80^{\circ}$ for $30 \mathrm{~min}$. with constant stirring. Polyvinylpyrrolidone (M.W. 35,000; Teva Ltd., Jerusalem) was dissolved in deionized water and sterilized by autoclaving. Dextran (M.W. 270,000; Pharmacia Ltd., Uppsala, Sweden) was dissolved in de-ionized water by heating at $80^{\circ}$ for 30 min. Amberlite resin IR-45 (British Drug Houses Ltd.) was added separately to each of the experimental tubes. The test tubes were autoclaved $\left(121^{\circ}, 10 \mathrm{~min}\right.$.) and the growth medium added aseptically.

Lipid extraction of bovine albumin. Bovine plasma albumin fraction V (Armour Laboratories, Hampden Park, Eastbourne, Sussex, England) was extracted according to Oyama, Steinman and Eagle (1953), with acetone or ethylene dichloride as solvent. Extraction with acetone was carried out as follows. Two volumes of acetone cooled to $-5^{\circ}$ were added slowly with stirring to one volume of ice-cold albumin solution (10\% w/v, $\mathrm{pH} \mathrm{4.9)}$. The mixture was stirred for $5 \mathrm{~min}$. and the precipitate formed was collected by centrifugation. The precipitate was dried under a stream of air and dissolved in de-ionized water to give a $10 \%(\mathrm{w} / \mathrm{v})$ solution. This solution was cooled to $0^{\circ}$ and a second extraction with acetone made as above. The extraction procedure was repeated for a third time and the resulting albumin precipitate was freeze-dried. Lipid extraction by ethylene dichloride was carried out by adding two volumes of ethylene dichloride to one volume of a $10 \%$ $(w / v)$ albumin solution. The mixture was stirred for $2 \mathrm{hr}$. at room temperature and then centrifuged at $3000 \mathrm{~g}$ for $3 \mathrm{~min}$. The upper aqueous layer was separated and re-extracted with ethylene dichloride, as above. The aqueous layer obtained after the second extraction was separated and freeze-dried. The dried material obtained 
after acetone or ethylene dichloride extraction was pulverized in a mortar and dissolved in de-ionized water. Addition of dilute alkali was sometimes necessary to obtain clear solutions. The albumin solution was adjusted to $\mathrm{pH} 8 \cdot 4$ and sterilized by filtration through sintered glass filters.

Isolation of the lipid extracted from bovine albumin. The supernatant fluids obtained in the acetone extraction procedure were collected. The acetone component of the fluid was evaporated under a stream of nitrogen and the water component by freezedrying. Acetone was added to the dry material to dissolve lipid and to precipitate traces of albumin which were present. After sedimentation of the precipitated albumin by centrifugation, the clear acetone solution was evaporated to dryness under a stream of nitrogen. The resulting greasy yellowish substance was dissolved in ethanol and added to the experimental tubes without further sterilization.

Hydrolysis of bovine albumin and trypsin. Acid hydrolysis of bovine albumin was done by heating its solution in $6 \mathrm{~N}-\mathrm{HCl}$ at $110^{\circ}$ for $10 \mathrm{hr}$. The hydrochloric acid in the hydrolysate was removed by evaporation at $80^{\circ}$ to $90^{\circ}$ and the residue freezedried. Bovine albumin and crystalline trypsin (twice crystallized; Nutritional Biochemicals Corporation) were hydrolysed enzymically according to a method devised by M. E. Tourtellotte \& H. J. Morowitz (personal communication). Solutions of these proteins (4 mg./ml.; pH 7.5) were autoclaved for $15 \mathrm{~min}$. to denature the protein. The resulting suspensions were cooled and agitated vigorously to disperse the precipitated protein. Five mg. crystalline trypsin were added to $25 \mathrm{ml}$. protein suspension and incubated at $37^{\circ}$ for $4 \mathrm{hr}$., with constant stirring. The enzymic process was stopped by autoclaving $\left(121^{\circ}\right)$ the reaction mixtures for $15 \mathrm{~min}$. The undigested protein was removed by centrifugation at $10,000 \mathrm{~g}$ for $10 \mathrm{~min}$. and the supernatant fluid separated and freeze-dried. The dry powders of the acid hydrolysates and enzymic hydrolysates were dissolved in de-ionized water and sterilized by autoclaving. Paper chromatography (Razin \& Cohen, 1963) showed that the acid hydrolysate consisted of amino acids only; the enzymic hydrolysates contained substantial amounts of peptides in addition to the amino acids.

\section{RESULTS}

\section{Lipid extraction of bovine albumin and its effect on growth}

Bovine plasma albumin fraction $\mathrm{V}$ was found to be essential for growth of Mycoplasma laidlawii strain A in the minimal medium of Razin \& Cohen (1963). The concentrations of albumin required to obtain good growth in this medium were rather high (Fig. 1). Lipid extraction of the bovine albumin almost completely abolished its growth-promoting properties. Figure 2 shows the gradual decrease in the growth-promoting activity of bovine albumin after repeated extractions with acetone. Extraction of bovine albumin with ethylene dichloride yielded similar results (see Fig. 6). The lipid component isolated from bovine albumin enabled growth of the test organism when added to medium containing lipid-extracted albumin. This lipid fraction had no effect on growth when added to medium containing un-extracted albumin (Fig. 3).

\section{Requirement for long-chain fatty acids}

The requirement of Mycoplasma laidlawii strain A for a lipid component or lipid components present in bovine plasma albumin prompted us to test the effect on 


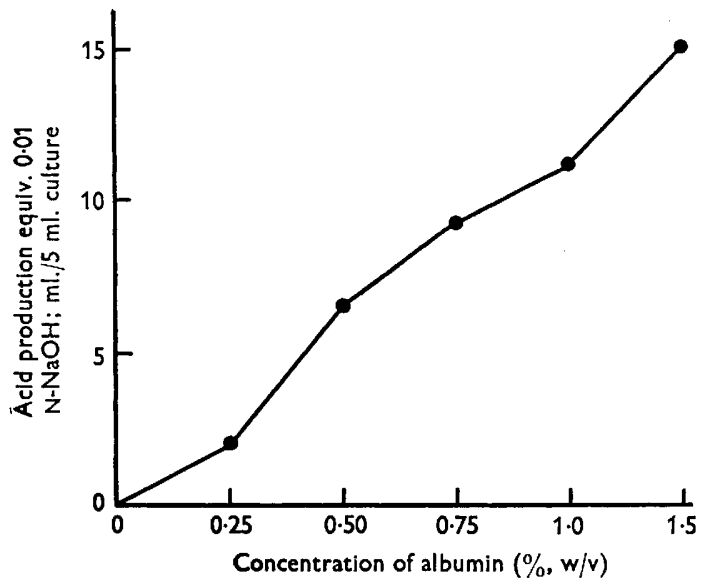

Fig. 1

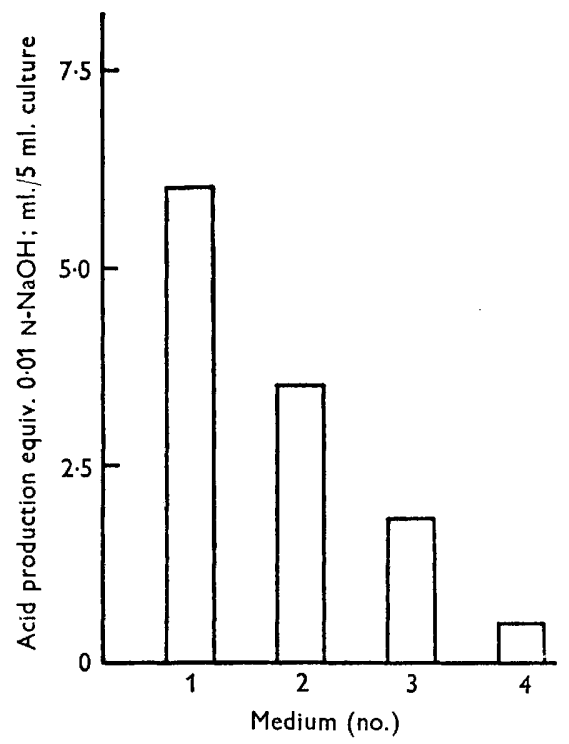

Fig. 2

Fig. 1. Growth of Mycoplasma laidlarwii strain A in the minimal medium of Razin \& Cohen (1963) with various concentrations of bovine plasma albumin fraction V.

Fig. 2. Growth of Mycoplasma laidlawii strain $A$ in the minimal medium containing $0.5 \%(w / v)$ of: (1) unextracted bovine albumin; (2) bovine albumin extracted once with acetone; (3) bovine albumin extracted twice with acetone; (4) bovine albumin extracted three times with acetone.

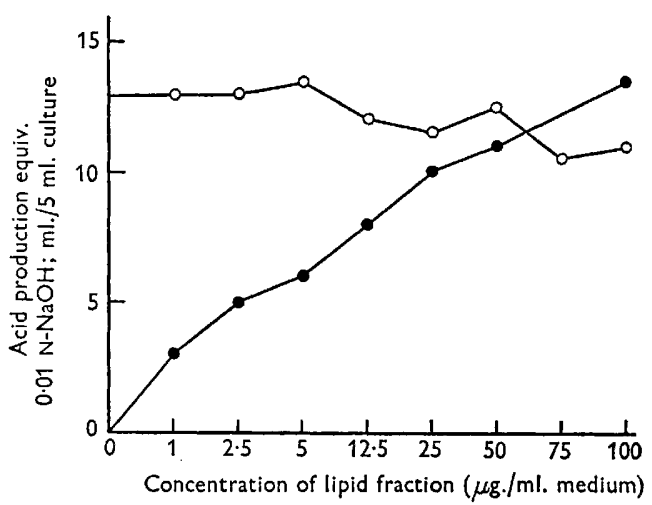

Fig. 3

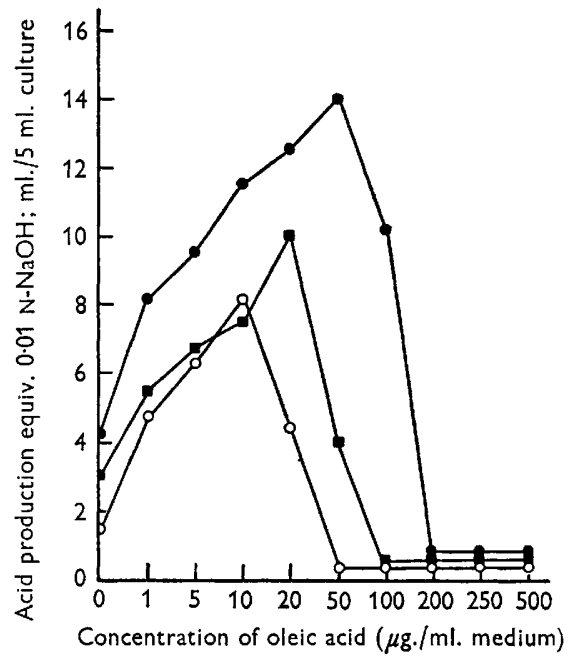

Fig. 4

Fig. 3. The effect of a lipid fraction isolated from bovine albumin on growth of $M y c o-$ plasma laidlawii strain A. The minimal medium contained $0.5 \%(\mathrm{w} / \mathrm{v})$ of unextracted bovine albumin $(O)$ or lipid-extracted bovine albumin $(\Theta)$.

Fig. 4. Effect of oleic acid on growth of Mycoplasma laidlarwii strain A in the minimal medium containing $0.1 \%, w / v(0), 0.25 \%, w / v(\square)$, or $0.5 \%, w / v(\bigcirc)$, lipid-extracted bovine albumin. 
growth of various long-chain fatty acids, which are known to contaminate bovine albumin preparations (Oyama, Steinman \& Eagle, 1953; Rodwell \& Abbot, 1961). Oleic acid restored completely the growth-promoting activity of lipid-extracted bovine albumin. Growth promotion by oleic acid could be demonstrated only within a certain range of concentrations. At higher concentrations oleic acid inhibited growth of $\boldsymbol{M}$. laidlawii. The toxic effect was decreased by increasing the albumin concentration in the medium (Fig. 4). The methyl ester of oleic acid was as active in growth promotion as oleic acid, but its toxicity was much lower. Linoleic and linolenic acids were less effective in growth promotion than oleic acid; among the saturated long-chain fatty acids lauric acid showed some growthpromoting activity. Palmitic and stearic acids did not replace the requirement of M. laidlawii strain A for oleic acid (Fig. 5). Addition of any of the saturated fatty acids to the growth medium containing oleic acid did not improve growth of the test organism. Biotin (in concentrations ranging between 0.0001 and $1.0 \mu \mathrm{g} . / \mathrm{ml}$. medium) did not replace the requirement of $M$. laidlawii strain a for oleic acid.

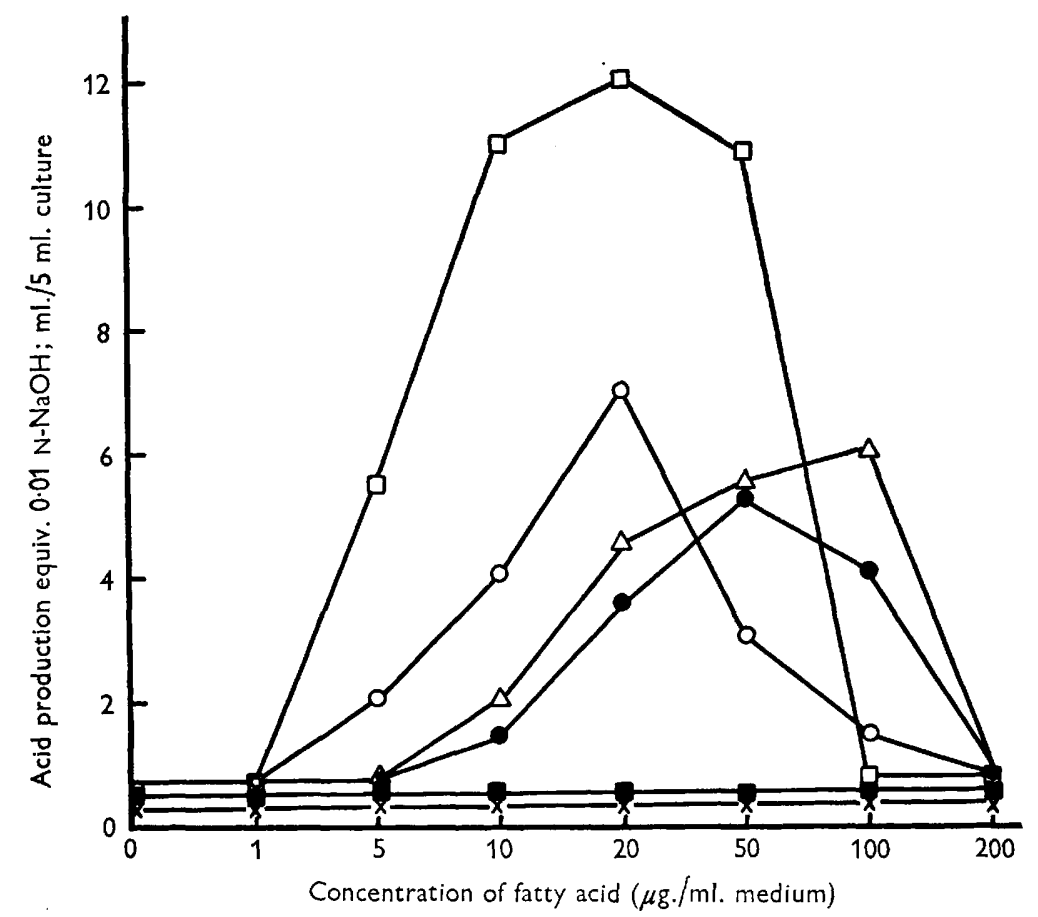

Fig. 5. Effect of saturated and unsaturated long-chain fatty acids on growth of Mycoplasma laidlawii strain A in minimal medium containing $0.5 \%(\mathrm{w} / \mathrm{v})$ lipid-extracted bovine albumin. Oleic acid $(\square)$; linolenic acid $(O)$; linoleic acid $(\triangle)$; lauric acid $(\bigcirc)$; palmitic acid (a); stearic acid $(\times)$.

\section{Effect of various Tweens on growth}

Tween 80 may provide a convenient source for oleic acid because of its higher solubility and lower toxicity. It enabled growth of Mycoplasma laidlawii strain A when added to the minimal medium containing lipid-extracted bovine albumin (Fig. 6). Growth of the test organism was usually best with $0.05 \%$ (w/v) of Tween 80 
when the concentration of lipid-extracted albumin was $0.5 \%(w / v)$ (Fig. 7). As with oleic acid, the toxic effect exhibited by high concentrations of Tween 80 was decreased by increasing the amount of albumin in the medium.

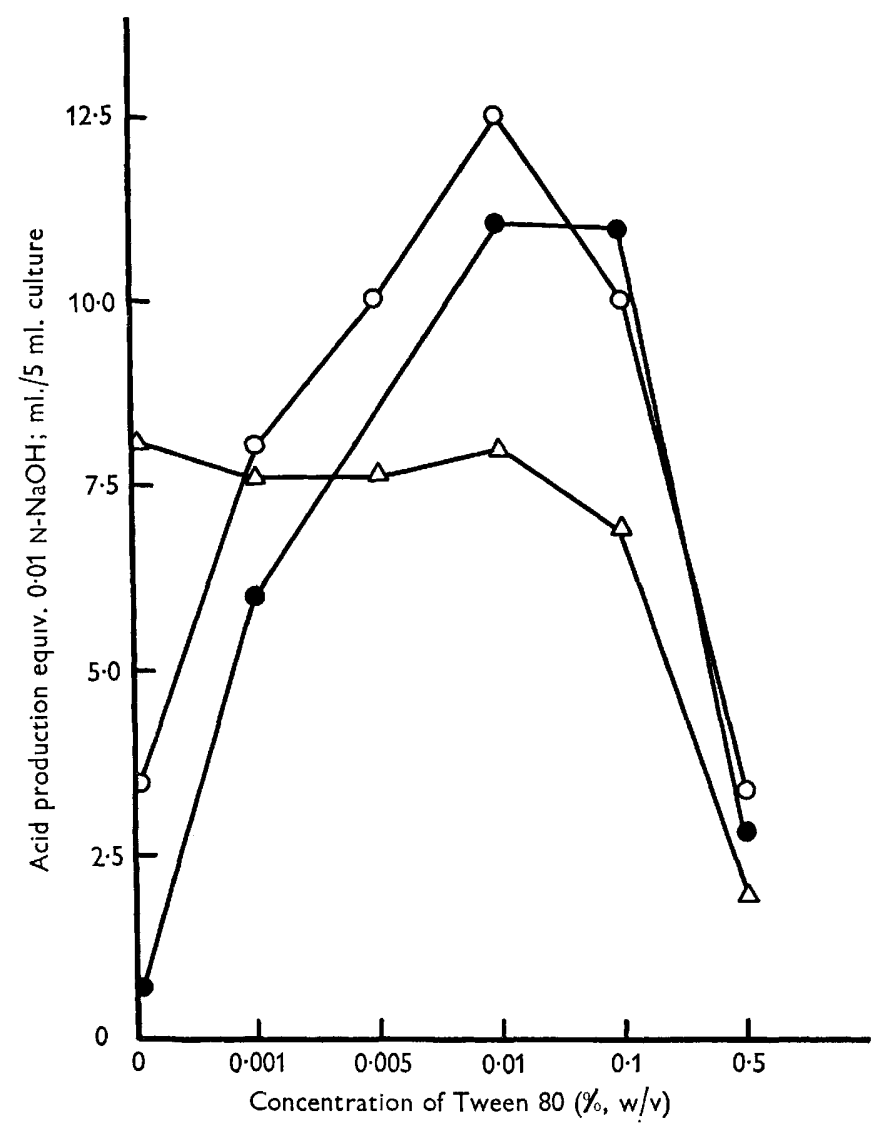

Fig. 6. Effect of Tween 80 on growth of Mycoplasma laidlawii strain A in the minimal medium containing: $0.5 \%(w / v)$ unextracted bovine albumin $(\triangle) ; 0.5 \%(w / v)$ bovine albumin extracted with ethylene dichloride $(O) ; 0.5 \%(w / v)$ bovine albumin extracted with acetone $(\mathbf{O})$.

Growth of Mycoplasma laidlawii with Tween 80 was always followed by the appearance of a yellow turbidity in the tubes, usually 1 or 2 days after the appearance of visible growth. Examination with the phase-contrast microscope of samples taken from the cultures showed the presence of yellow granules. The number of Mycoplasma organisms in the cultures tested decreased as the number of the yellow granules increased. These granules were isolated by centrifugation, washed and extracted with heptane + water + isopropanol $(36+28+36$, by vol.) according to Dole \& Meinertz (1960). The extract contained long-chain fatty acids as determined by titration with $0.01 \mathrm{~N}-\mathrm{NaOH}$ with Nile blue as indicator. These findings indicated that $M$. laidlawii was capable of splitting Tween 80 enzymically. To verify this finding, Edward medium plates containing various concentrations of Tween $80(0.05$ to $1.0 \%, \mathrm{w} / \mathrm{v})$ and $\mathrm{CaCl}_{2}(0.01 \%, \mathrm{w} / \mathrm{v})$ were heavily inoculated with $M$. laidlawii. After 2 days of incubation at $37^{\circ}$ many granules and crystalline needles appeared 
in and above the region of growth (the 'film and spots' described by Edward, 1954). Similar granules and needles appeared when a drop of pancreatic lipase solution was placed on the plates. The crystalline needles apparently represent free oleic acid; they melted on gentle warming. The granules apparently represent calcium and magnesium salts of oleic acid (Stitt, Clough \& Branham, 1948).

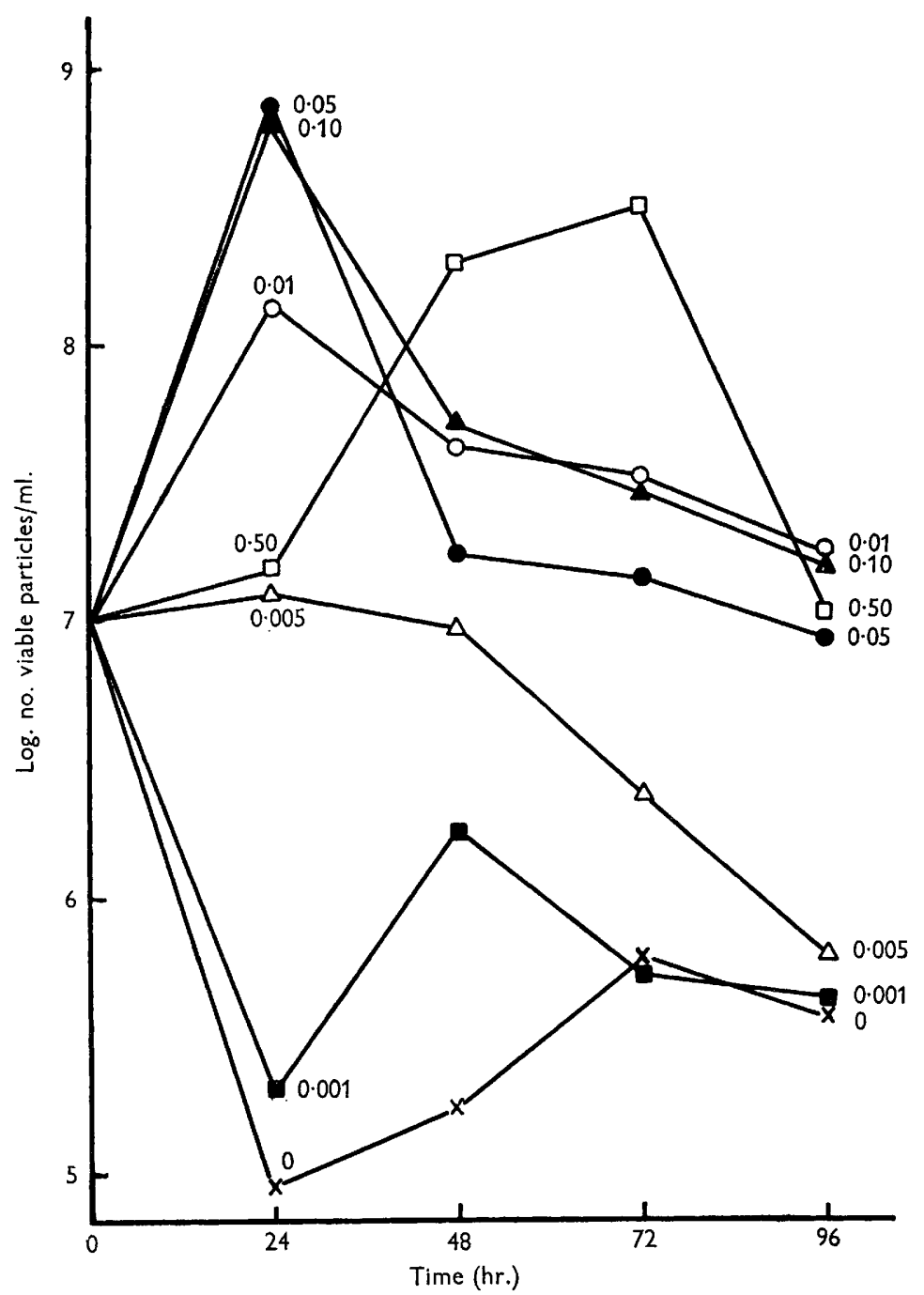

Fig. 7. Growth of Mycoplasma laidlawii strain $\mathrm{A}$ in the minimal medium containing various amounts $(\%, w / v$ as indicated) of Tween $80+0.5 \%(w / v)$ lipid-extracted bovine albumin.

The effects on the growth of Mycoplasma laidlawii of Tween 20, where lauric acid constitutes the fatty acid component, Tween 40 (which contains palmitic acid) and Tween 60 (which contains stearic acid) are presented in Fig. 8. The growthpromoting activity of Tween 20 was higher than that of Tween 40 and Tween 60, and less than that of Tween 80. 
The experiments described so far were carried out with Mycoplasma laidlawii strain A. Experiments with $M$. laidlawii strain B and the oral saprophytic strain isolated from the human mouth showed these strains also to be able to grow in the minimal medium of Razin \& Cohen (1963), and that their fatty acid requirements were the same as those of $\boldsymbol{M}$. laidlarwii strain A.

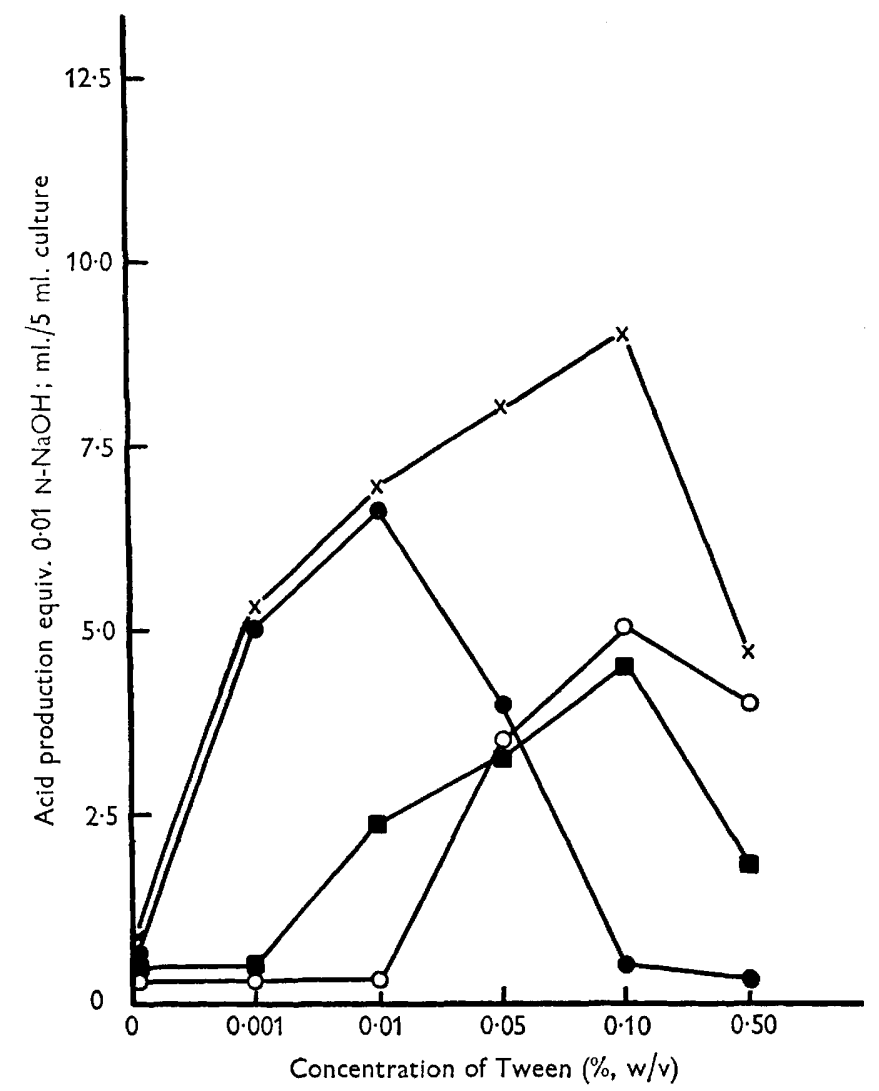

Fig. 8. Effect of various Tweens on growth of Mycoplasma laidlawii strain A in the minimal medium containing $0.5 \%(w / v)$ lipid-extracted bovine albumin. Tween $20(0)$; Tween 40 (O); Tween $60(\square)$; Tween $80(x)$.

Experiments to replace bovine albumin in the minimal medium

Acid or enzymic hydrolysis of bovine albumin completely destroyed its growthpromoting activity. The hydrolysates of bovine albumin were tested in concentrations ranging between 0.01 and $1 \%(\mathrm{w} / \mathrm{v})$ with or without Tween 80 (in concentrations between 0.0001 and $1 \%, w / v)$. The tryptic digest by crystalline trypsin was likewise unable to replace albumin when tested alone and with different concentrations of Tween 80 . Tween 80 itself, when added to the minimal medium without bovine albumin, did not support growth of Mycoplasma laidlawii. An experiment to obtain growth of the test organism with Tween 80 in the absence of albumin was done according to the method of Oyama et al. (1953). The minimal medium without bovine albumin was made semisolid by adding Noble agar (Difco) to $0 \cdot 4 \%(w / v)$. A small volume of a washed suspension of $M$. laidlawii strain A was added to the 
semisolid medium at $42^{\circ}$ and well mixed. The medium was dispensed in $15 \mathrm{ml}$. quantities into sterile tubes. After cooling, $1 \mathrm{ml}$. portions of sterile Tween 80 solution (in concentrations of $0 \cdot 1,0.5,1,5 \%, w / v$ ) were placed on the surface of the solid medium. After 1 week of incubation at $37^{\circ}$ no growth was seen. In a control tube which contained the minimal medium $+0.5 \%(\mathrm{w} / \mathrm{v})$ lipid-extracted bovine albumin and a layer of $1 \%(\mathrm{w} / \mathrm{v})$ Tween 80 growth was seen $1 \mathrm{~cm}$. below the Tween 80 layer and downwards. Cholesterol (in concentrations of 1 to $500 \mu \mathrm{g} . / \mathrm{ml}$.) and protamine sulphate $(0.5$ to $50 \mu \mathrm{g} . / \mathrm{ml}$.) did not replace bovine albumin when added to the minimal medium, with or without Tween 80 . These substances did not improve the poor growth obtained with low concentrations of bovine albumin, and protamine sulphate even inhibited growth in concentrations higher than $25 \mu \mathrm{g} . / \mathrm{ml}$.

Several polymers reported to replace albumin or other essential proteins in growth media for micro-organisms and tissue cells were tested for ability to replace bovine albumin in the minimal medium. Polyvinylpyrrolidone $(0.01$ to $1 \%$, w/v), methylcellulose (0.01 to $0.5 \%, \mathrm{w} / \mathrm{v})$, dextran (0.01 to $2 \%, \mathrm{w} / \mathrm{v})$ and Amberlite IR-45 (3.5 to $15 \%, \mathrm{w} / \mathrm{v}$ ) did not support growth of Mycoplasma laidlawii strain A in minimal medium without albumin, when tested alone or with several concentrations of Tween $80(0.01$ to $1 \%, \mathrm{w} / \mathrm{v})$. None of these polymers improved the poor growth obtained with low concentrations of albumin, and thus could not replace even part of the requirement of $M$. laidlawii for bovine albumin.

\section{DISCUSSION}

The lipid extracted from bovine plasma albumin fraction $\mathrm{v}$ apparently contains long-chain fatty acids known to be present in appreciable quantities in serum albumin preparations (Oyama et al. 1953; Goodman, 1957). Of the fatty acids tested, oleic acid showed the highest growth-promoting activity for Mycoplasma laidlarwii. Numerous micro-organisms have been reported to require long-chain fatty acids, especially oleic acid (see reviews by Pollock, 1949; Nieman, 1954; Hutner \& Holz, 1962). In the Mycoplasma group of organisms, M. mycoides var. mycoides was found to require for growth a saturated and an unsaturated long-chain fatty acid (Rodwell, 1956; Rodwell \& Abbot, 1961). Long-chain fatty acids were found to stimulate growth of a mycoplasma strain isolated from man (Smith \& Boughton, 1960). The finding that also the saprophytic Mycoplasma strains require a long-chain fatty acid for growth appears to indicate that this is a common requirement for mycoplasmas in general. M. laidlawii, however, has been found to differ from $M$. mycoides var. mycoides in not requiring a saturated fatty acid for growth.

The role played by the long-chain fatty acids in the growth of Mycoplasma is not yet clear. Smith \& Boughton (1960) suggested that the long-chain fatty acids stimulate growth of parasitic Mycoplasma organisms by increasing the water solubility of the cholesterol required for growth. This cannot explain the requirement of the saprophytic mycoplasmas for long-chain fatty acids, since these do not require cholesterol for growth (Rothblat \& Smith, 1961; Razin \& Cohen, 1963). Rodwell \& Abbot (1961) suggested that the long-chain fatty acids are needed for the synthesis of an undetermined cell component necessary for the structural integrity of the Mycoplasma cell. This hypothesis fits well with the finding that oleic acid added to the growth medium was incorporated by several Mycoplasma species, including $M$. laidlawii (Smith \& Boughton, 1960). The possible incorporation 
of oleic acid into the lipid component of the Mycoplasma cell-membrane is now under investigation in our laboratory.

Tween 80 replaced the requirement of Mycoplasma laidlawii for oleic acid. Our results indicate that $M$. laidlawii contains a lipase which can split Tween 80 and liberate free oleic acid. The liberated oleic acid, in small concentrations, promotes growth, while at higher concentrations it inhibits growth and causes lysis of the organisms (Edward \& Fitzgerald, 1951; Rodwell, 1956; Smith \& Boughton, 1960). The mycoplasmas, which are devoid of cell walls (Razin, 1963), are very sensitive to lysis by surface-active agents (Razin \& Argaman, 1963). The poor growth of $M$. laidlawii with Tween 40 or Tween 60 may be explained by contamination of these commercial products with small amounts of oleic acid (Shorb \& Lund, 1959; Boné \& Parent, 1963).

The bovine albumin component of the medium of Razin \& Cohen (1963) thus serves as a carrier for essential unsaturated fatty acids. Albumin may be regarded as a buffer for oleic acid, binding and releasing it into the growth medium in minute non-toxic amounts (Davis \& Dubos, 1947; Pollock, 1949), but this is not necessarily its only function in the growth of $M$. laidlarwii. Cholesterol, known to bind long-chain fatty acids and to neutralize their toxic effects (Kodicek, 1949; Rodwell, 1956; Butler \& Knight, 1960b) cannot replace albumin in the growth medium. Negative results were also obtained with the weakly basic resin, Amberlite IR-45, which was incorporated by Johnson \& Wilson (1960) into a defined medium for Leptospira pomona to detoxify acidic substances such as fatty acids. Charcoal was likewise unable to replace the requirement of $M$. laidlawii for albumin (Razin \& Cohen, 1963). Thus it seems that the supply and neutralization of long-chain fatty acids is not the sole function of albumin for Mycoplasma.

Albumin may provide a source of essential amino acids and peptides (Piez, Oyama, Levintow \& Eagle, 1960). Its growth-promoting activity for Mycoplasma laidlawii is, however, abolished by acid or enzymic hydrolysis. Peptides obtained by tryptic digestion of crystalline ribonuclease or trypsin are able to promote growth of $\boldsymbol{M}$. laidlawii strain B in a protein-free defined medium (M. E. Tourtellotte and H. J. Morowitz; personal communication). These peptides were unable to replace albumin in our medium. Protamine sulphate, which replaced the serum protein requirement of several tissue cell strains (Neuman \& Tytell, 1960) was unable to replace albumin in our medium. Albumin may also serve to provide an adequate physical environment for growth of the plastic mycoplasmas (cf. Salzman, 1961). Several polymers found to replace the protein requirement of tissue cells in culture, e.g. dextran, polyvinylpyrrolidone (Katsuta et al. 1959), methylcellulose (Merchant $\&$ Hellman, 1962), had no such effect in the growth medium of $M$. laidlawii. The question whether bovine albumin has other functions besides that of a carrier of essential fatty acids still remains unanswered.

We thank Miss Ahuva Knyszynski for her valuable help during part of this study.

\section{REFERENCES}

Boné, G. J. \& Parent, G. (1963). Stearic acid, an essential growth factor for Trypanosoma cruzi. J. gen. Microbiol. 31, 261.

Butler, M. \& KNIGHT, B. C. J. G. (1960a). The survival of washed suspensions of Mycoplasma. J. gen. Microbiol. 22, 470. 
Butler, M. \& KNight, B. C. J. G. (1960b). Steroid growth requirements and steroid growth inhibitors of Mycoplasma. J. gen. Microbiol. 22, 483.

Davis, B. D. (1947). The preparation and stability of fatty acid-free polyoxyethylene sorbitan monoleate ('Tween' 80). Arch. Biochem. 15, 359.

Davis, B. D. \& Dubos, R. J. (1947). The binding of fatty acids by serum albumin, a protective growth factor in bacteriological media. J. exp. Med. 86, 215.

Dole, V. P. \& Meinertz, H. (1960). Microdetermination of long-chain fatty acids in plasma and tissue. J. biol. Chem. 235, 2595.

EDward, D. G. ff. (1954). The pleuropneumonia group of organisms: a review, together with some new observations. J. gen. Microbiol. 10, 27.

Edward, D. G. ff. \& Fitzgeram, W. A. (1951). Cholesterol in the growth of organisms of the pleuropneumonia group. J. gen. Microbiol. 5, 576.

Goodman, D. S. (1957). Preparation of human serum albumin free of long-chain fatty acids. Science, 125, 1296.

Hutner, S. H. \& Holz, G. G. Jr. (1962). Lipid requirements of microorganisms. Ann. Rev. Microbiol. 16, 189.

Johnson, R. C. \& Wilson, J. B. (1960). Nutrition of Leptospira pomona. J. Bact. 80, 406.

Katsuta, H., Takaoka, T., Hosaka, S., Hibino, M., Otsuki, I., Hattori, K., Suzuki, S. \& Mrtamura, K. (1959). Protein requirements of rat ascites hepatoma cells in tissue culture. Japan. J. exp. Med. 29, 45.

KoDicex, E. (1949). The effect of unsaturated fatty acids on Gram-positive bacteria. Symp. Soc. exp. Biol. 3, 217.

Merchant, D. J. \& Hellman, K. B. (1962). Growth of L-M strain mouse cells in a chemically defined medium. Proc. Soc. exp. Biol., N.Y. 110, 194.

Neuman, R. E. \& Tytell, A. A. (1960). Serumless medium for cultivation of cells of normal and malignant origin. Proc. Soc. exp. Biol., N.Y. 104, 252.

Nieman, C. (1954). Influence of trace amounts of fatty acids on the growth of microorganisms. Bact. Rev. 18, 147.

Oyama, V. I., Steinman, H. G. \& Eagle, H. (1953). The nutritional requirements of treponemata $\mathrm{V}$. A detoxified lipide as the essential growth factor supplied by crystallized serum albumin. J. Bact. 65, 609.

Piez, K. A., Oyama, V. I., Levintow, L. \& Eagle, H. (1960). Proteolysis in stored serum and its possible significance in cell culture. Nature, Lond. 188, 59.

Pollock, M. R. (1949). The effects of long-chain fatty acids on the growth of Haemophilus pertussis and other organisms. Symp. Soc. exp. Biol. 3, 193.

RAzIN, S. (1962). Nucleic acid precursor requirements of Mycoplasma laidlarwii. J. gen. Microbiol. 28, 243.

Razin, S. (1963). Structure, composition and properties of the PPLO cell envelope. Recent progress in Microbiology, VIII, p. 526. Ed. by N. E. Gibbons. Toronto : University Press.

Razin, S. \& Argaman, M. (1963). Lysis of Mycoplasma, bacterial protoplasts, spheroplasts and L-forms by various agents. J. gen. Microbiol. 30,155 .

Razin, S. \& Cohen, A. (1963). Nutritional requirements and metabolism of Mycoplasma laidlawii, J. gen. Microbiol. 30, 141.

Razin, S. \& KNight, B. C. J. G. (1960a). A partially defined medium for the growth of Mycoplasma. J. gen. Microbiol. 22, 492.

Razin, S. \& KNIGHT, B. C. J. G. (1960b). The effects of ribonucleic acid and deoxyribonucleic acid on the growth of Mycoplasma. J. gen. Microbiol. 22, 504.

Razin, S., Michmann, J. \& Shimshoni, Z. (1964). The occurrence of Mycoplasma (pleuropneumonia-like organisms, PPLO) in the oral cavity of dentulous and edentulous subjects. $J$. dent. Res. (in the Press).

Razin, S. \& Ourver, O. (1961). Morphogenesis of Mycoplasma and bacterial L-form colonies. J. gen. Microbiol. 24, 225.

Rodwell, A. W. (1956). The role of serum in the nutrition of Asterococcus mycoides. Aust. J. biol. Sci. 9, 105.

RoDwell, A. W. \& Aввот, A. (1961). The function of glycerol, cholesterol and long-chain fatty acids in the nutrition of Mycoplasma mycoides. J. gen. Microbiol. 25, 201. 
Rothblat, G. H. \& Smith, P. F. (1961). Nonsaponifiable lipids of representative pleuropneumonia-like organisms. J. Bact. 82, 479.

Salzman, N. P. (1961). Animal cell cultures. Science, 133, 1559.

Shorb, S. \& LuNd, P. G. (1959). Requirements of trichomonads for unidentified growth factors, saturated and unsaturated fatty acids. J. Protozool. 6, 122.

Smith, P. F. \& Boughton, J. E. (1960). Role of protein and phospholipid in the growth of pleuropneumonia-like organisms. J. Bact. 80, 851 .

Stitt, E. R., Clough, P. W. \& Branham, S. E. (1948). Practical Bacteriology, Hematology and Parasitology, loth ed., p. 852. New York: The Blakiston Co. 